\title{
Correction to: Roadside monkeys: anthropogenic effects on moor macaque (Macaca maura) ranging behavior in Bantimurung Bulusaraung National Park, Sulawesi, Indonesia
}

\author{
Erin P. Riley ${ }^{1} \mathbb{D} \cdot$ Christopher A. Shafer ${ }^{2} \mathbb{D} \cdot$ Joshua S. Trinidad $^{1} \mathbb{D} \cdot$ Kristen S. Morrow $^{1,3} \mathbb{D} \cdot$ Cristina Sagnotti $^{4,6,7} \mathbb{D}$. \\ Monica Carosi ${ }^{4,5}$ (D) Putu Oka Ngakan ${ }^{6}$ (i)
}

Published online: 24 August 2021

(c) Japan Monkey Centre 2021

\section{Correction to: Primates (2021) 62:477-489 https://doi.org/10.1007/s10329-021-00899-6}

In the original publication of the article, the percentage of feeding records on roadside-provisioned foods after the shift (2015-present) listed in Table 2 is incorrect. The correct value is $36 \%$.
Publisher's Note Springer Nature remains neutral with regard to jurisdictional claims in published maps and institutional affiliations.

The original article can be found online at https://doi.org/10.1007/ s10329-021-00899-6.

Erin P. Riley

epriley@sdsu.edu

1 Department of Anthropology, San Diego State University, 5500 Campanile Drive, San Diego, CA 92182-6040, USA

2 Department of Anthropology, Grand Valley State University, Grand Rapids, MI, USA

3 Department of Anthropology, University of Georgia, Athens, GA, USA

4 Department of Biology, Tor Vergata University, Rome, Italy

5 Department of Sciences, Roma Tre University, Rome, Italy

6 Faculty of Forestry, Hasanuddin University, Makassar, Sulawesi, Indonesia

7 Department of Life Sciences and Biotechnology, University of Ferrara, Ferrara, Italy 